Agro-Science Journal of Tropical Agriculture, Food, Environment and Extension Volume 10 Number 2 Mav 2011 pp. 16-28

ISSN 1119-7455

\title{
SPATIAL VARIABILITY OF PARTICLE SIZES OF COASTAL PLAIN SANDY SOILS OF SOUTHEASTERN NIGERIA
}

\author{
Obi J. C., Ogban, P. I. and Utuk, I. I. \\ Department of Soil Science, University of Uyo, Uyo, Nigeria.
}

\begin{abstract}
Geostatistical analysis facilitates site-specific farming, soil and sanitary landfill management, sustainability and health. The objectives of this study were to assess the extent of variability, spatial dependence and structure of soil particle sizes, pedological and management implications in the coastal plain sands soils of southeastern Nigeria. Surface $(0-15 \mathrm{~cm})$ and subsurface $(15-30 \mathrm{~cm})$ soil samples were collected at $10 \mathrm{~m}^{2}$ intervals (rigid grid nodes) in a $100 \mathrm{~m}$ by $100 \mathrm{~m}$ plot at the one year fallowed portion of Teaching and Research / Commercial Farm of University of Uyo, in Use Offot, Uyo, Nigeria. A total of 100 samples were collected for each depth. Coefficient of variation (CV) of silt: clay ratio (SCR), silt, fine and coarse sand (surface) were highly variable at both soil depths, while coarse sand of subsurface soil was least variable (13.8\%). Spatial dependence of the variables ranged from strong to moderate. The moderately spatially dependent variables included fine sand (36.7\%), coarse sand (48.7\%) on the surface, and SCR (33.7\%) on the subsurface, while the remaining variables were strongly spatially dependent. Pearson correlation coefficients between the semivariances of the two depths showed significance in $52.8 \%$ of the entire relationships compared to $19.4 \%$ observed on the measured values of the particle sizes. Stronger spatially dependent variables correlated with more variables compared to the moderately spatially dependent variables. It was observed that most of the kriged maps produced displayed similarity in the sedimentation or depositional characteristics which now followed the depositional effect of the massive erosive forces. Kriging may combine correlation and spatial dependence to facilitate site specific farming, soil and sanitary landfills management, knowledge of pedogenesis and sustainability in the coastal plain sands soils.
\end{abstract}

Keywords: coastal plain sands, spatial structure, soil variability, particle sizes, pedogenesis

\section{INTRODUCTION}

Particle size fractions (PsF) are the most important attributes affecting physical and chemical processes in the soil. The relative distribution of particle size fractions largely determines water, heat, nutrient fluxes, water and nutrient holding capacity and soil surface form and stability. Variation in soil texture directly contributes to the variation in nutrient storage and availability, water retention, availability and transport hence may influence the yield potential of any site. Warric and Gardner (1983) found a significant impact of psf variability on soil performance and crop yield. Similarly, variability in soil texture component is a primary factor influencing crop yield. Reynolds (1970) and Crave and Gascuel-Odoux, (1997) found that variation in soil moisture content was directly related to the soil textural variability.

Coastal plain sands are unconsolidated sediments consisting series of white or honey- coloured clayey sands with few bands and beds of clays. They are nonmarine fluvio-Lacustrine deposits and were laid in a series of large shallow lagoons and lakes. Coastal plain sands soils vary from sand on the surface to fine loamy subsurface soils. Duffera et al., (2007) indicated that the physical properties of coastal plain sands soils which describe majority of within field variability include soil texture, soil water content, plant available water and penetrometer resistance and these variables could be useful in development of management zones for site specific crop management. Soils formed on coastal plain sands of southeastern Nigeria are characterized by the dominance of sandy textured fragment and low organic matter content (Ojanuga et al. 1981, Ofomata. 1981, Ogban and Ekerette, 2001). Hence the physical properties of these soils tend to attract more research attention. Generally, soils exhibit continuous change (variability) both in space and time. 
This variation is usually considered to be problematic in relation to sampling effort, quality of information, optimal soil management, environmental sustainability and health. Soil variability is a product of soil forming factors that interact over a continuum of spatial and temporal scales. Therefore the precision of statement that could be made about soil properties and management depend largely on the amount of variability of soil properties. Precision agriculture utilizes the outcome of spatial analysis of soil properties for sustainable optimal crop production and environmental management. This becomes more important in the coastal plain sand soils that structurally have problems associated with leaching of agrochemical and management of sanitary landfills (Ibia et al., 2009) due to high sand and low clay + silt content within its profiles (Ogban and Ekerette, 2001).

To further underscore the emphasis on particle sizes of coastal plain sands soils, Duffera et al. (2007) reported that some soil physical properties such as texture, soil water content and plant available water showed significant spatial structure and could be a useful guide in soil management and crop production. Additionally, there is an established significant correlation between particle sizes, their derivatives and solute transport in soils (Strock, et al., 2001), and other physical properties (Mbagwu et al., 1983, Ogban and Ekerette, (2001) and their mineralogy (Souza et al., 2009). The indication that variation of texture is largely associated with soil formation that may have been inherited led to the allusion by Cambardella et al. (1994) that strongly spatially dependent soil properties were controlled by intrinsic variation in soil characteristics such as texture and mineralogy. The nugget semivariance expressed as a percentage of the total semivariance enables comparison of the relative size of the nugget effect among soil properties (Trangmar et al. 1985). Several studies (Iqbal et al. 2005; Duffera et al. 2007; Santra et al. 2008; Souza et al. 2009, Obi and Nnadi, 2010, Obi et al., 2010a, and b) have shown that components of soil texture are strongly spatially dependent. Thus, influencing other soil properties (physical, chemical or biological) that may equally display strong spatial dependence. For instance, Shukla et al. (2004) reported that bulk density, soil organic carbon, matrix flux potential, electrical conductivity, clay and total nitrogen were moderately spatially dependent, strongly correlate with each other and therefore functions of intrinsic variation in texture and mineralogy. Similar analogy was also drawn by Obi and Ogunkunle (2009), Iqbal et al. (2005) and Botros et al., (2009). The objective of this work was to establish the implications of spatial structure of soil particle sizes on the management of coastal plain sands soils of southeastern Nigeria.

\section{MATERIALS AND METHODS Site description and sampling}

The study was conducted on a plot at University of Uyo Teaching and Research / Commercial farm in the Use Offot area of Uyo in Akwa Ibom State in southeastern Nigeria (Fig. 1). The plot was previously used for undergraduate Internship (Telferia occidentalis and Talinum Triangulare production) programme but presently under fallow dominated by Pennisetum digitatum $(>80 \%)$. Akwa Ibom State is located approximately between longitudes $4^{\circ} 30^{\prime}$ and $5^{\circ} 30^{\prime} \mathrm{E}$ and latitudes $7^{\circ} 30^{\prime}$ and $8^{\circ} 30^{\prime} \mathrm{N}$ within a tropical climate characterized by rainy season (February/March - November) and dry season (November - February/March). Rainfall ranges from $3000 \mathrm{~mm}$ along the Atlantic coast to $2000 \mathrm{~mm}$ in the hinterland (Peters, et al., 1989) with overall topography typically of unconsolidated marine and fluvial deposit formation. The State falls within the sedimentary areas of Nigeria with up to $80 \%$ of the soil formed on coastal plain sands and alluvium (Ojanuga et al., 1981; Ofomata, 1981) comprising the whole of the southern and central parts of the State. Soils on coastal plain sands are normally deep, dominantly sandy with low clay, organic matter content and $\mathrm{pH}$. In the field, surface $(0-$ $15 \mathrm{~cm})$ and subsurface $(15-30 \mathrm{~cm})$ samples were collected on an almost flat terrain $(100 \mathrm{~m}$ by $100 \mathrm{~m})$ plot at $10 \mathrm{~m}^{2}$ intervals (i.e. grid nodes) with the aid of Dutch auger. Ten replicate samples were collected perpendicularly to the direction of the slope, with 10 observation points parallel to the slope to give a total of 100 sample points per soil depth. Samples were processed and particle size analysis was carried out (Gee and Bauder, 1986).

\section{Statistical analysis}

Measured variables in the data set were analyzed using classical statistical methods to obtain descriptive statistics, measure of central tendency and normality of distribution (Shapiro and Wilk, 1965) using SAS Institute (1996) with the aid of Proc univariate normal. A one-way Analysis of variance (ANOVA) was performed to compare each variable between the soil depths using a protected least significant $(\mathrm{p} \leq 0.05)$. Correlation analysis of the particle sizes were performed among and between the depths (SAS Institute, 1996). The measured variables that were either skewed or kurtous were transformed either using natural logarithm (Parkin and Robinson,1992) or square root methods to a nearly normal distribution before using geostatistical analysis, then, the data were back transformed using a weighted technique. A weighted technique is considered superior to a simple back transformation because it more closely approximates true population statistics (Haan, 1997). 


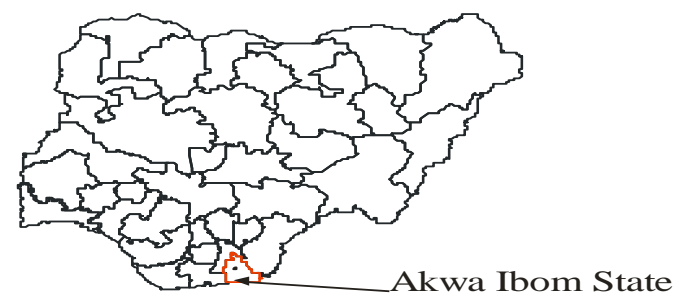

Fig. 1: Map of Nigeria showing - Uyo in Akwa Ibom State.

The degree of spatial variability for each variable was determined by geostatistical methods using semivariogram analysis and kriging (Trangmar et al., 1985; Bailey and Gatrell, 1998; McBratney and Pringle, 1999). Before applying the geostatistical tests, each variable was checked for normality, trend, and anisotropy. A geographic trend was determined using exploratory data analysis tools in Spatial Module of S-Plus (S-Plus, 1997). If a variable had a geographic trend, then a first-order (linear) model was developed between soil variable $z$ (dependent variable) and the $x, y$ geographic coordinates (independent variables). The linear trend model was tested as an ordinary regression by ANOVA. If the linear trend model was significant $(\mathrm{p} \leq 0.05)$, then the soil variable was detrended by subtracting the soil variable values from the linear model calculations. The residuals were regarded as closer to stationary and were used to calculate semivariograms. The residual interpolation was performed with ordinary kriging. Finally, adding the kriged residuals to the first order trend completed the mapping of the variate. Since the exact form of semivariogram model was never known, the given model selected and used was only an approximation of its function (Journel and Huijbregts, 1978). However, to come up with a best model, a jack-knifing procedure was performed. In this trial-and-error method, every known point was estimated using the surrounding data points but not the measured data point. Thus, every semivariogram for each soil variable was adjusted by trial and error until a best fit between the estimated and actual values was found (Bailey and Gatrell, 1998). A semivariogram was determined for each variable to ascertain the degree of spatial variability between neighboring observations, and the appropriate model function fitted to the semivariogram. The semivariogram function (Goovaerts, 1997) was calculated as

$\gamma(h)=\frac{1}{2 N(h)} \sum_{i=1}^{N}\left[Z\left(x_{i}\right)-Z\left(x_{i}+h\right)\right]^{2}$ where $\mathrm{h}$ is the lag distance

$\gamma(h)$ is the semivariance at lag h,

$\mathrm{Z}$ is a random variable (value of soil property),

$\mathrm{Z}\left(\mathrm{x}_{\mathrm{i}}\right)$ is random variable for a fixed location $\mathrm{x}_{\mathrm{i}}$,

$\mathrm{N}(\mathrm{h})$ is the number of pairs of values $\mathrm{Z}\left(\mathrm{x}_{\mathrm{i}}\right)$,

$\mathrm{Z}\left(\mathrm{x}_{\mathrm{i}}+\mathrm{h}\right)$ separated by a vector $\mathrm{h}$.

The three basic parameters which describe spatial structure of semivariogram plots comprised

$\gamma(h)=C_{0}+C_{1}$

where $C_{0}$ is the nugget effect,

$C_{l}$ is the structural variance,

$a$ the range of spatial dependence and

$C_{0}+C_{l}$ is the sill

On the semivariances of the soil particle sizes, Pearson correlation analysis was performed both among and between the sampling depths (SAS Institute, 1996). Finally contour maps of each variable at each depth were created through ordinary kriging (David, 1977; Journel and Huijbregts, 1978; and Clark, 1979) using their respective semivariogram models in Spatial Module of S-Plus (S-Plus, 1997).

\section{RESULTS AND DISCUSSION \\ Variations and relationships between soil particle sizes}

The mean and median were used as primary estimates of central tendency, while standard deviation, coefficient of variation (CV), skewness, kurtosis, minimum and maximum were used as estimates of variability (Table 1). It was observed that silt clay ratio (SCR) of the subsurface soil was skewed while all the soil properties were kurtous with the exception of silt + clay, clay, fine sand and coarse sand of surface soil, then fine sand of the subsurface soil. Despite skewness and kurtosis, the mean and median values were similar, with median equal, greater or less (with maximum of 13 points) than the mean for most of the soil particle sizes (Table 1). These showed that outlier did not dominate the measure of central tendency. Shulka et al., (2004) and Obi and Ogunkunle (2009) reported similarity of means and median of several physical, chemical and biological soil properties. On the surface, the $\mathrm{CV}$ of coarse sand was less than $15 \%$ (least variable), silt + clay and clay ranged between $>15 \%$ and $\leq 35 \%$ (moderately 
Table 1: Descriptive statistics of the particle size distribution $\left(\mathrm{g} \mathrm{kg}^{-1}\right)$ of coastal plain sands soil

\begin{tabular}{|c|c|c|c|c|c|c|c|c|c|c|}
\hline Soil property & $\begin{array}{l}\text { Standard } \\
\text { Error }\end{array}$ & $\begin{array}{l}\text { Standard } \\
\text { deviation }\end{array}$ & $\begin{array}{l}\text { Coefficient } \\
\text { variability }\end{array}$ & of & Skewness & Kurtosis & Min. & Max & Median & Mean* \\
\hline & & & $\underline{0-15 \mathrm{~cm}}$ & & & & & & & \\
\hline Silt + clay & 3.32 & 33.2 & 17.34 & & 1.33 & 3.07 & 114.0 & 328.0 & 182.0 & $192.7 \mathbf{a}$ \\
\hline Silt: clay ratio & 0.02 & 0.17 & 82.79 & & 1.88 & 4.30 & 0.04 & 0.88 & 0.16 & $0.20 \mathrm{a}$ \\
\hline Clay & 2.74 & 27.37 & 16.94 & & 0.05 & 2.07 & 60.6 & 260.0 & 161.2 & 161.6b \\
\hline Silt & 2.34 & 23.43 & 76.91 & & 2.05 & 5.85 & 6.0 & 134.0 & 28 & $30.4 a$ \\
\hline Fine sand & 6.28 & 62.62 & 44.26 & & 0.01 & -0.38 & 14.0 & 280.0 & 140 & 141.9a \\
\hline Coarse sand & 6.38 & 63.77 & $\begin{array}{l}9.58 \\
15-30 \mathrm{~cm}\end{array}$ & & 0.06 & 0.03 & 512 & 836.0 & 667.3 & 665.3a \\
\hline Silt + clay & 3.08 & 38.03 & 18.86 & & 0.04 & 7.06 & 22 & 335.2 & 202 & 201.6a \\
\hline Silt: clay ratio & 0.02 & 0.16 & 96.63 & & 2.28 & 6.08 & 0.01 & 0.83 & 0.12 & $0.17 a$ \\
\hline Clay & 3.30 & 33.02 & 10.11 & & -1.90 & 8.05 & 16.8 & 240.0 & 174.0 & 172.8a \\
\hline Silt & 2.34 & 23.55 & 89.79 & & 2.73 & 10.52 & 1.10 & 146.0 & 19.4 & 26.0a \\
\hline Fine sand & 6.85 & 68.45 & 54.16 & & 0.35 & -0.69 & 20.0 & 300.0 & 117.0 & $126.4 b$ \\
\hline Coarse sand & 9.18 & 91.64 & 13.80 & & -1.88 & 8.92 & 146.0 & 798.0 & 678.0 & $665.5 \mathrm{a}$ \\
\hline
\end{tabular}

*alphabets compared similar soil properties at different depths

Table 2: Semivariance statistics of the particle size distribution of coastal plain sands soil

\begin{tabular}{|c|c|c|c|c|c|c|c|c|c|c|c|c|}
\hline & $\begin{array}{l}\text { Silt+ } \\
\text { clay }\end{array}$ & $\begin{array}{l}\text { Slit: clay } \\
\text { ratio }\end{array}$ & Clay & Silt & Fine sand & $\begin{array}{l}\text { Coarse } \\
\text { sand }\end{array}$ & $\begin{array}{l}\text { Silt+ } \\
\text { clay }\end{array}$ & $\begin{array}{l}\text { Silt: clay } \\
\text { ratio }\end{array}$ & Clay & Silt & $\begin{array}{l}\text { Fine } \\
\text { sand }\end{array}$ & $\begin{array}{l}\text { Coarse } \\
\text { sand }\end{array}$ \\
\hline \multicolumn{7}{|c|}{ - } & \multicolumn{6}{|c|}{ - } \\
\hline Nugget(Co) & 33.46 & 0.001 & 65.67 & 30.25 & 617.94 & 815.00 & 34.54 & 29.43 & 38.00 & 29.80 & 287.07 & 1660.00 \\
\hline Sill (Co+C) & 362.66 & 0.005 & 328.27 & 125.27 & 1685.04 & 1674.80 & 618.25 & 87.43 & 421.14 & 168.53 & 2188.76 & 24260.02 \\
\hline Range & 100.00 & 80.00 & 100.00 & 90.00 & 90.00 & 30.00 & 80.00 & 70.00 & 60.00 & 100.00 & 100.00 & 45.00 \\
\hline $\mathrm{Co} / \mathrm{Co}+\mathrm{C}$ & 9.23 & 20.74 & 20.00 & 24.15 & 36.67 & 48.66 & 5.59 & 33.66 & 9.02 & 17.68 & 13.12 & 6.84 \\
\hline $\mathbf{R}^{2}$ & 0.95 & 0.96 & 0.92 & 0.97 & 0.97 & 0.94 & 0.91 & 0.94 & 0.74 & 0.98 & 0.98 & 0.99 \\
\hline
\end{tabular}

variable), SCR, silt and fine sand were greater that $35 \%$ (highly variable). Whereas subsurface clay and coarse sand were less than $15 \%$, silt + clay was $>15 \%$ but $<35 \%$, and SCR, silt and fine sand were $>35 \%$. Generally, it was observed that SCR, silt, fine and coarse sand (surface) were highly variable at both depths, while coarse sand $(13.8 \%)$ of subsurface soil was least variable. Low variability of particle sizes of $<0.002 \mathrm{~mm}$ (clay) had previously been reported by Obi and Ogunkunle, (2009) on the soils of sandstones origin in the Guinea Savanna region of Nigeria. The silt: clay ratio of the surface $(0.20)$ and subsurface $(0.17)$ soils were not significantly different from each other in as much as that of the surface was higher than the subsurface as a characteristic of weathering intensities within the profiles of alfisosl (Mbagwu et al., 1983)

The Pearson correlation (Table 2) among the particle sizes and their derivatives indicated that, at the $0-15 \mathrm{~cm}$ depth, there was significant correlation between silt + clay and clay, silt, fine sand $(\mathrm{r}=0.69,0.51,-0.29$ respectively, $\mathrm{p}<0.01)$ and SCR $(\mathrm{r}=0.24, \mathrm{p}<0.05)$. There were also significant correlations between fine sand and clay $(\mathrm{r}=0.27, \mathrm{p}<0.01)$ and coarse sand $(\mathrm{r}=-0.76$, $<0.01)$, SCR and clay $(-0.42, \mathrm{P}<0.01)$ and SCR and silt $(r=0.92,0.01)$. Additionally, at the $15-30 \mathrm{~cm}$ depth, silt + clay significantly correlated with SCR $(\mathrm{r}=0.25, \mathrm{p}<0.05)$, clay, silt and coarse sand $(\mathrm{r}=$ $0.41,0.40$ and -0.34 respectively, $\mathrm{p}<0.01$ ), while SCR highly significantly correlated with clay and silt ( -0.50 and 0.84 respectively). The relationships established at the $0-15 \mathrm{~cm}$ and $15-30 \mathrm{~cm}$ depths were similar with the exception of fine and coarse sand which significantly correlated with silt + clay in either of the depths but not in both. Fine sand at the subsurface did not significantly correlate with any of the listed variables.

Correlation between particle sizes of the surface and subsurface soils indicated that there were relationships between few variables. There were significant correlations among the following variables at the different depths; silt + clay $(r=$ $0.22, \mathrm{p}<0.05)$, clay $(\mathrm{r}=0.26, \mathrm{p}<0.01)$, fine sand $(\mathrm{r}$ $=0.53, \mathrm{p}<0.01)$ and coarse sand $(\mathrm{r}=0.38, \mathrm{p}<0.01)$, between fine sand on the surface and coarse sand of subsurface soil $(\mathrm{r}=-0.57, \mathrm{p}<0.01)$ indicating that they actually influence each other but not vary independently.

\section{Spatial structure analysis}

However, as descriptive statistics could not discriminate between intrinsic (natural as a result of soil forming factors) and extrinsic (imposed by management and land use) sources of variability and as data were collected at grid nodes 
Obi J. C., Ogban, P. I. and Utuk, I. I.

Table 3: Pearson correlation coefficient of soil particle sizes at different depths

\begin{tabular}{|c|c|c|c|c|c|c|c|c|c|c|c|c|}
\hline & & $\begin{array}{l}\text { Silt+ } \\
\text { clay }\end{array}$ & SCR & clay & silt & Fine sand & $\begin{array}{l}\text { Coarse } \\
\text { sand }\end{array}$ & Silt+ clay & SCR & clay & silt & $\begin{array}{l}\text { Fine } \\
\text { sand }\end{array}$ \\
\hline & & \multicolumn{6}{|c|}{ 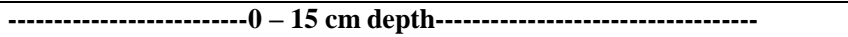 } & \multicolumn{5}{|c|}{ 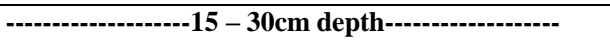 } \\
\hline Silt + clay & $\dot{1}$ & & & & & & & & & & & \\
\hline SCR & $\overrightarrow{\boldsymbol{u}}$ & $0.24 *$ & & & & & & & & & & \\
\hline Clay & $\cong$ & $0.69 * *$ & $-0.42 * *$ & & & & & & & & & \\
\hline Silt & $\hat{\theta}$ & $0.51 * *$ & $0.92 * *$ & $-0.42 * *$ & & & & & & & & \\
\hline Fine sand & 菣 & $-0.29 * *$ & -0.04 & $0.27 * *$ & -0.11 & & & & & & & \\
\hline Coarse sand & & -0.16 & -0.05 & -0.11 & -0.11 & $-0.76 * *$ & & & & & & \\
\hline Silt + clay & $\overrightarrow{\boldsymbol{r}}$ & 0.22 & 0.07 & 0.17 & 0.04 & 0.07 & 0.26 & & & & & \\
\hline SCR & $\therefore$ & 0.11 & 0.09 & -0.04 & 0.15 & 0.06 & 0.06 & $0.25 *$ & & & & \\
\hline Clay & 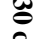 & $0.26 * *$ & 0.02 & $0.26 * *$ & -0.10 & 0.04 & $0.41 * *$ & $-\mathbf{0 . 5 0} * *$ & & & & \\
\hline Silt & $\Xi$ & 0.18 & 0.11 & 0.01 & 0.19 & -0.04 & -0.15 & $0.40 * *$ & $0.84 * *$ & -0.10 & & \\
\hline Fine sand & $\hat{\theta}$ & -0.08 & -0.08 & -0.03 & -0.10 & $0.53 * *$ & $-0.46 * *$ & 0.12 & -0.01 & -0.01 & 0.02 & \\
\hline Coarse sand & $\underline{\exists}$ & -0.07 & -0.05 & -0.04 & -0.01 & $-0.35 * *$ & $0.38 * *$ & $-0.34 * *$ & -0.10 & -0.13 & -0.18 & $-0.69 * *$ \\
\hline
\end{tabular}

Table 4: Pearson correlation coefficient of semivariance of soil particle sizes at different depths

\begin{tabular}{|c|c|c|c|c|c|c|c|c|c|c|c|c|}
\hline & & $\begin{array}{l}\text { Silt+ } \\
\text { clay }\end{array}$ & SCR & clay & silt & Fine sand & $\begin{array}{l}\text { Coarse } \\
\text { sand }\end{array}$ & $\begin{array}{l}\text { Silt+ } \\
\text { clay }\end{array}$ & SCR & clay & silt & $\begin{array}{l}\text { Fine } \\
\text { sand }\end{array}$ \\
\hline & & \multicolumn{6}{|c|}{ - } & \multicolumn{5}{|c|}{ 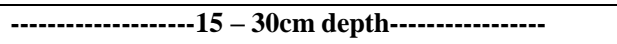 } \\
\hline Silt + clay & $\stackrel{0}{1}$ & & & & & & & & & & & \\
\hline SCR & $\vec{U}$ & 0.43 & & & & & & & & & & \\
\hline Clay & $\cong$ & $0.95 * *$ & 0.32 & & & & & & & & & \\
\hline Silt & $\hat{\theta}$ & 0.51 & $0.89 * *$ & 0.43 & & & & & & & & \\
\hline Fine sand & $\stackrel{\overbrace{}}{\rightleftarrows}$ & $0.93 * *$ & $0.64 *$ & $0.87 * *$ & $0.79 * *$ & & & & & & & \\
\hline Coarse sand & & 0.35 & 0.59 & 0.20 & 0.34 & 0.34 & & & & & & \\
\hline Silt + clay & $\vec{\pi}$ & $0.67 *$ & $0.84 * *$ & 0.51 & $0.83 * *$ & $0.80 * *$ & $0.71 *$ & & & & & \\
\hline SCR & $\therefore$ & 0.54 & 0.48 & 0.62 & $0.77 * *$ & $0.72 *$ & -0.02 & 0.53 & & & & \\
\hline Clay & 局 & $0.82 * *$ & 0.51 & $0.72 *$ & 0.49 & $0.77 * *$ & $0.77 * *$ & $0.83 * *$ & 0.41 & & & \\
\hline Silt & $\Xi$ & $-0.98 * *$ & -0.36 & $0.94 * *$ & 0.45 & $-0.90 * *$ & -0.42 & $-0.67 *$ & -0.55 & $-0.88 * *$ & & \\
\hline Fine sand & $\frac{2}{2}$ & $-0.99 * *$ & -0.40 & $-0.95 * *$ & -0.48 & $-0.92 * *$ & -0.36 & $-0.67 *$ & -0.56 & $-0.84 * *$ & $0.98 * *$ & \\
\hline Coarse sand & $\vec{\Xi}$ & $-0.74 *$ & 0.05 & $-0.85 * *$ & -0.06 & -0.59 & 0.24 & -0.04 & -0.39 & -0.30 & $0.69 *$ & $0.73^{*}$ \\
\hline
\end{tabular}

for spatial analysis, then spatial dependence was investigated among the soil particle sizes. Several models were fitted to the variograms, but linear models were obtained (Cambardella et al., 1994) as the best fits. Semivariograms produced were shown as parts of Figures $2-7$. The semivariance parameters of the particle size distribution of the soils were shown in Table 2. The range of lag distances of the particle sizes were between 30 and $100 \mathrm{~m}$. All variables showed positive nugget effect which may be as a result of sampling error, random, inherent variability or shorter range variability compared to chosen grid size. The spatial class ratio presented by Cambardella et al., (1994) was adopted in definition of certain distinctive classes of spatial dependence.

There were highly significant correlations (i.e. of semivariances) between fine sand and silt + clay, SCR, and silt $(\mathrm{r}=0.93,0.87$ and 0.79 respectively) and clay $(\mathrm{r}=0.64, \mathrm{p} \leq 0.05)$, silt + clay and clay $(r=0.95)$, then SCR and silt $(r=0.89)$ of the surface soil. On the subsurface, fine sand significantly correlated with clay and silt ( -0.84 and 0.98 respectively, $\mathrm{p} \leq 0.01)$, silt + clay, and coarse sand $(\mathrm{r}=-0.67,0.73$ respectively, $\mathrm{p} \leq 0.05)$. Additionally, silt + clay displayed significant correlations with clay $(\mathrm{r}=0.83, \mathrm{p} \leq 0.01)$ and $\operatorname{silt}(\mathrm{r}=$ $0.67, \mathrm{p} \leq 0.05)$ ). Correlation between the calculated semivariances at the two depths showed significance in 19 out of $36(52.8 \%)$ relationships shown in Table 4. This was in contrast to 7 out of $36(19.4 \%)$ observed on the measured values of the variables (Table 3). These indicated that semivariance actually improved the quality of the variables and their ability to help in the explanation of the characteristics of the soil particle size distribution, their relationship with each other and by implications soil formation processes (Trangmar et al., 1985).

These results may not be unrelated with the fact that majority of the variables $(75 \%)$ were strongly spatially dependent whereas the remaining (25\%) were moderately spatially dependent. The variables that were more strongly spatially dependent correlated with more variables than less strongly or moderately spatially dependent variables when comparisons were done between semivariances. The realization that stronger spatially dependent variables correlated with more of the other variables compared to the 
Silt + Clay $(0-15 \mathrm{~cm})$

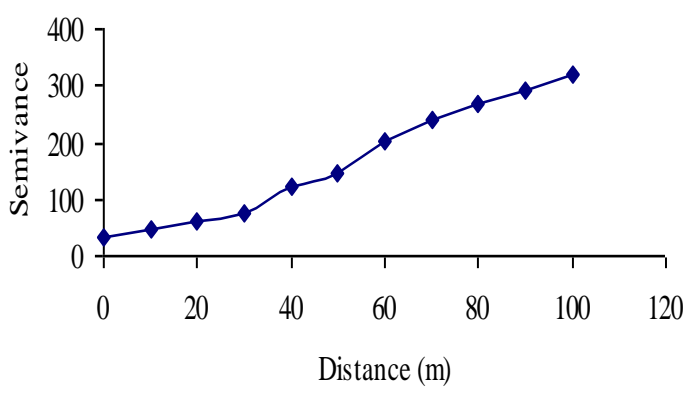

Silt + Clay $(15-30 \mathrm{~cm})$

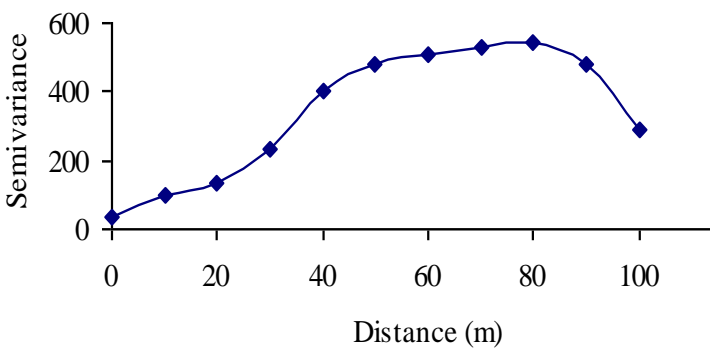

Silt + clay $(0-15 \mathrm{~cm})$
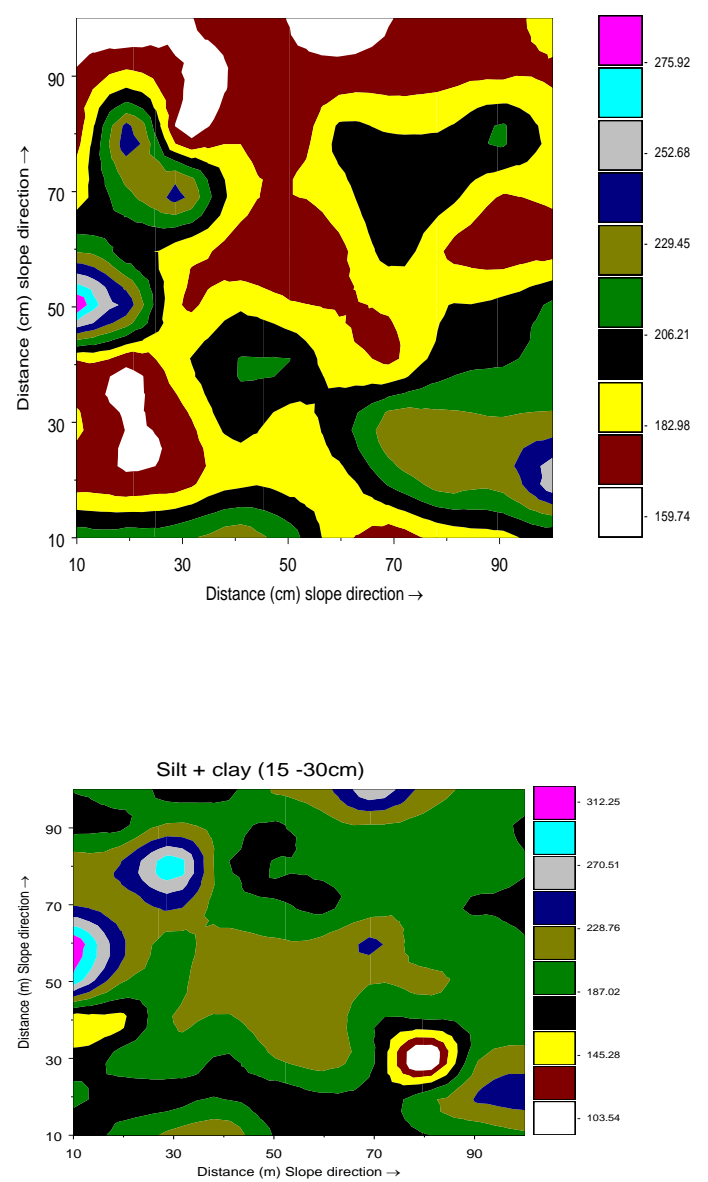

Fig. 2: Semivariograms (left) and kriged maps (right) of silt + clay $\left(\mathrm{g} \mathrm{kg}^{-1}\right)$ for surface $(0-15 \mathrm{~cm})$ and subsurface $(15-30 \mathrm{~cm})$ soils.

moderately spatially dependent variables further supported the fact that strong spatial dependence implied intrinsic variability as such variables could influence the distribution of other ancillary or subordinate variables and subsequently correlated with one another. Strongly spatially dependent properties have been reported to be controlled by intrinsic variations in soil characteristics, such as texture and mineralogy, whereas extrinsic factors such as fertilizer application and tillage control the variability of weakly spatially dependent parameters.

The nugget semivariance expressed as a percentage of the total semivariance enables comparison of the relative size of the nugget effect among soil properties a confirmation of Trangmar et al., (1985). These ratios were used to define distinct classes of spatial dependence for the soil variables as follows: if the ratio was $<25 \%$, the variable was considered strongly spatially dependent, if the ratio was between 25 and $75 \%$, the variable was considered moderately spatially dependent; and if the ratio was $>75 \%$, the variable was considered weakly spatially dependent. The range of spatial dependence of the soil particle size distribution varied between $5.6 \%$ (silt + clay at the $15-30 \mathrm{~cm}$ depth) to $48.7 \%$ (coarse sand at the $0-$ $15 \mathrm{~cm}$ depth). Actually, silt + clay recorded the least nugget: sill ratio at the two depths (Table 2) when compared with other textural fractions. Generally, the spatial dependence of particle size distributions and their components ranged from strong to moderate. The moderately spatially dependent variables include fine sand $(36.7 \%)$, coarse sand $(48.7 \%)$ on the surface, and SCR $(33.7 \%)$ on the subsurface, while the remaining variables were strongly spatially dependent. This corresponded with the observation made by Iqbal et al., (2005) in 

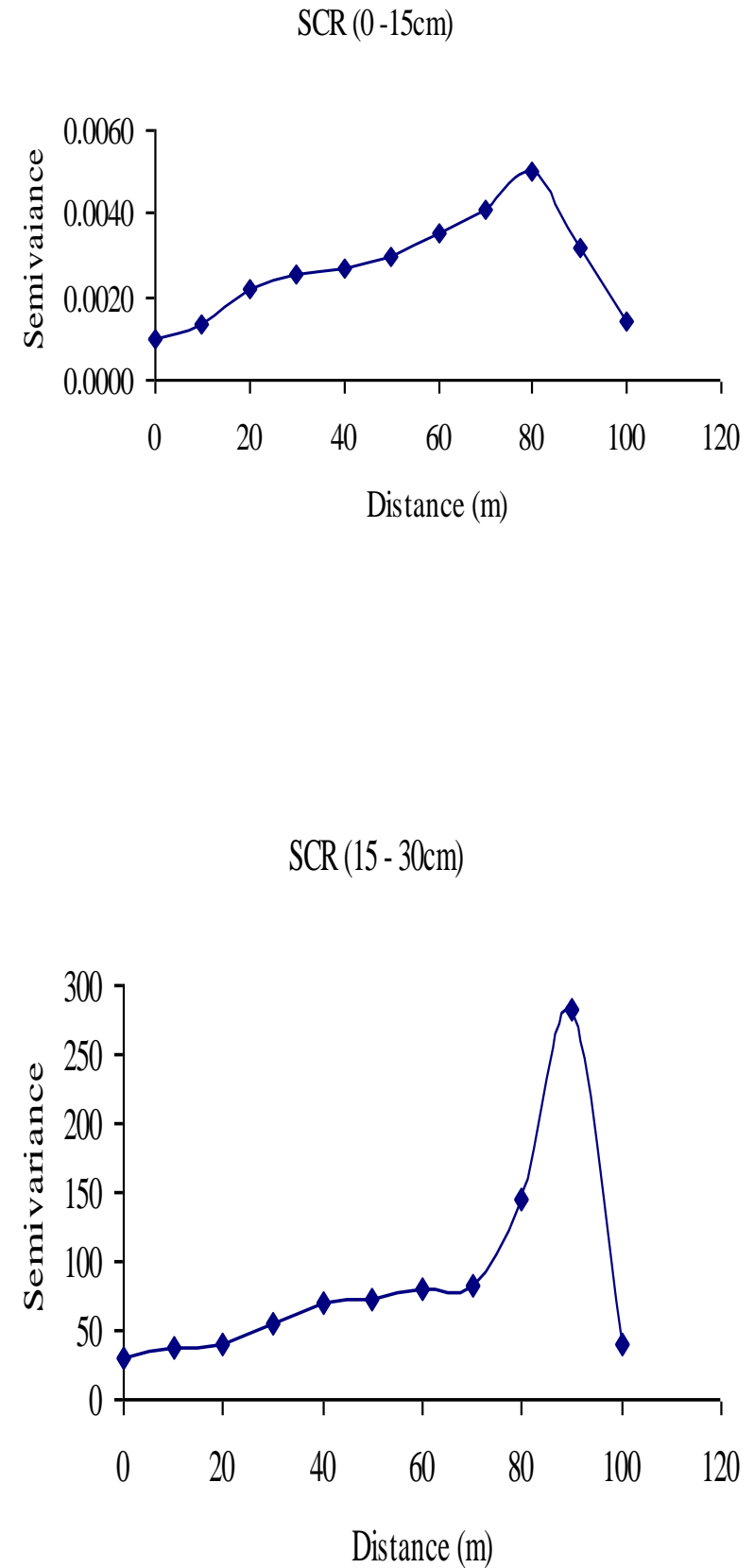
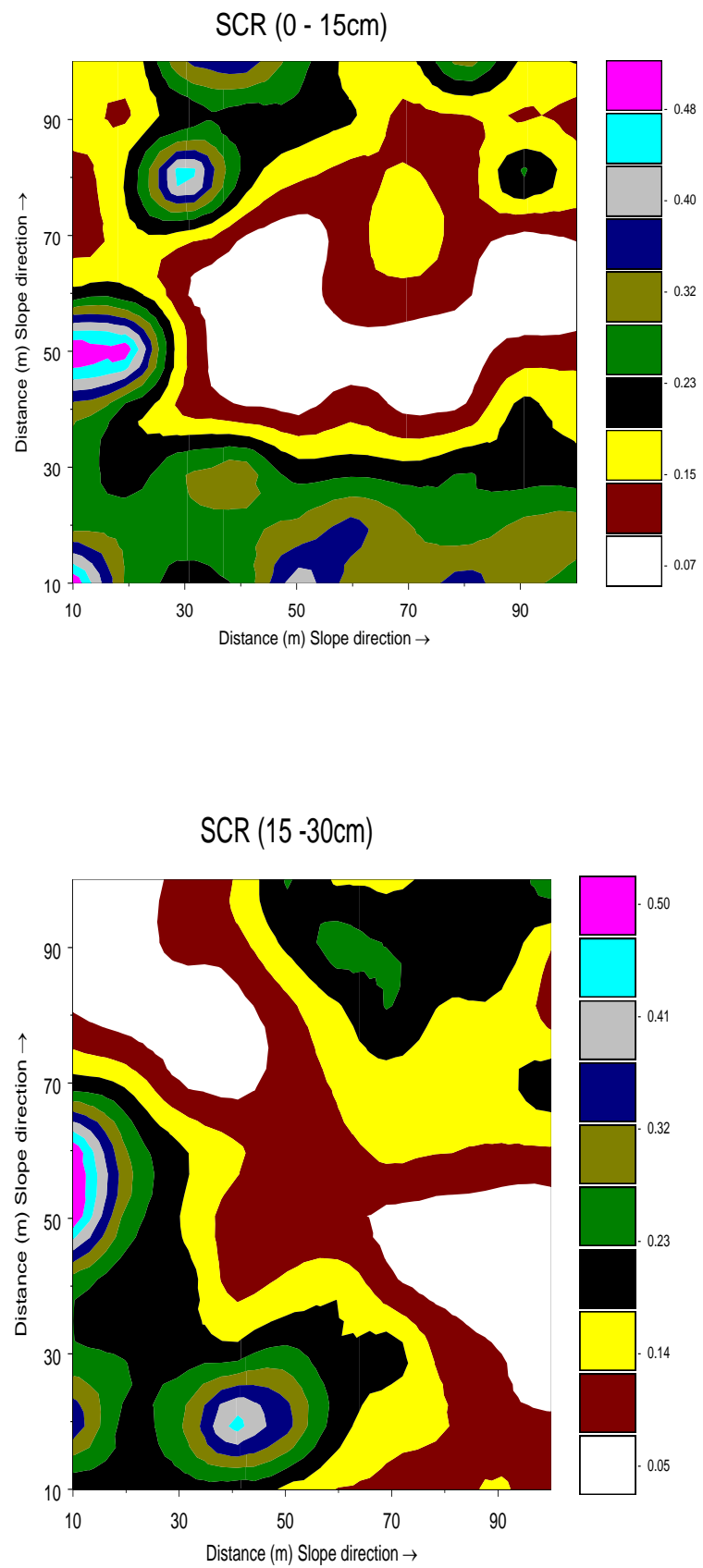

Fig. 3: Semivariograms (left) and kriged maps (right) of silt: clay ratio (SCR) for surface $(0-15 \mathrm{~cm})$ and subsurface $(15-30 \mathrm{~cm})$ soils

their study on spatial variability analysis of soil physical properties of alluvial soils. They reported that geostatistical analysis illustrated that spatial dependent stochastic components were predominant over the nugget effects. The simple statistics indicated that the sand fractions were dominated by coarse sand that ranged between 512.0 and $836.0 \mathrm{~g}$ $\mathrm{kg}^{-1}\left(\right.$ mean $\left.=665.3 \mathrm{~g} \mathrm{~kg}^{-1}\right)$ on the surface and 146.0 and $798.0 \mathrm{~g} \mathrm{~kg}^{-1}$ (mean $=665.5 \mathrm{~g} \mathrm{~kg}^{-1}$ ) at the subsurface compared with the fine sand that ranged between 14.0 and $280.0 \mathrm{~g} \mathrm{~kg}^{-1}$ on the surface and 20.0 and $300.0 \mathrm{~g} \mathrm{~kg}^{-1}$ on the subsurface (Table 1). Yet, it was both fine sand and coarse sand of the surface soil that had highest nugget: sill ratio. Equally it was the sand and clay fractions that had lowest lag distances that were $30 \mathrm{~m}$ and $60 \mathrm{~m}$ respectively, followed closely by SCR that had lag distance of $70 \mathrm{~m}$. These results may indicate the combined influence of surface tillage and stratification of different sediments at different scales 
(Vauclin et al. 1983; Iqbal et al., 2005). It is noteworthy to state that the study area is situated at the lowest portion on the landscape that experiences continual reception of material carried in a massive erosive activity from the upper portion of the landscape under the influence of torrential rainfall during the prolonged rainy season duration which spans between March and November of each year (Ojanuga et al. 1981, Ofomata. 1981, Ogban and Ekerette, 2001). The mean SCR were 0.20 and 0.17 (no significant difference, $\mathrm{p} \leq 0.05$ ) on the surface and subsurface soils respectively indicating that these soils were not highly weathered according to Olaleye et al., (2000) which stated that SCR $<0.15$ indicates highly weathered soils. Therefore moderate spatial dependence of SCR may equally be intrinsically stratification processes rather than tillage which as practiced in the study area was mainly surface tillage for production of Telferia occidentalis and Talinum triangulare vegetables.

\section{Interpolation of the particle size fractions}

The establishment of spatial structure for the soil particle sizes led to the production of
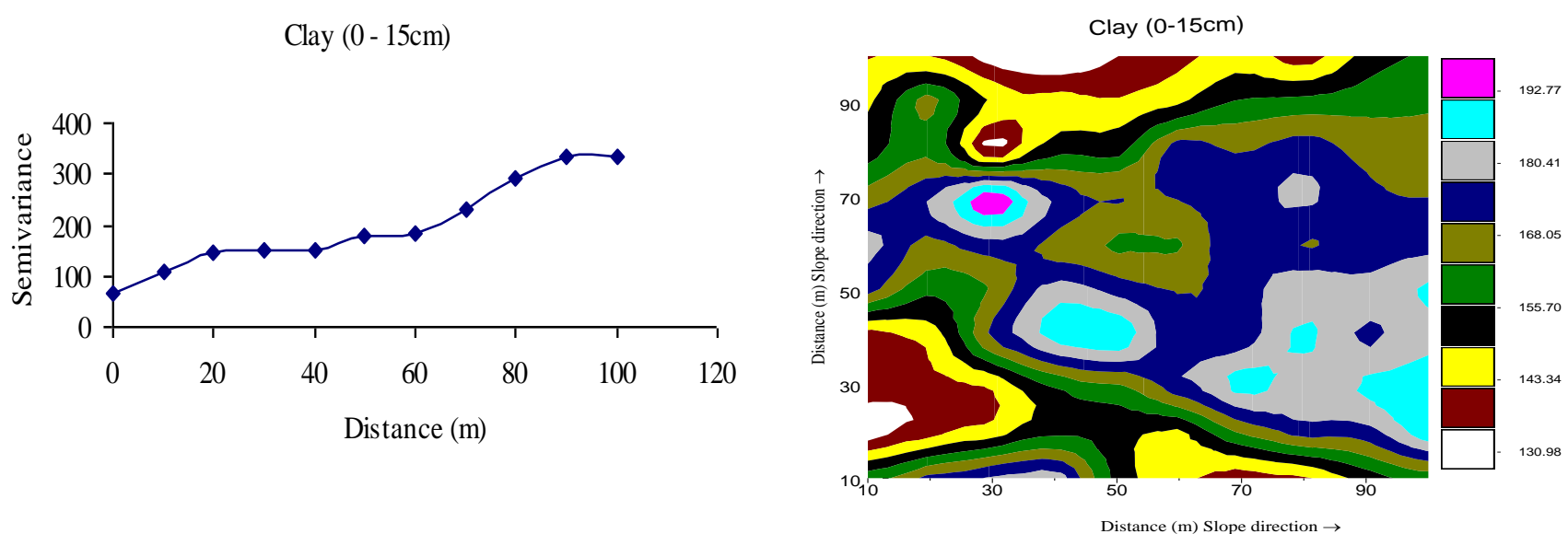

Clay $(15-30 \mathrm{~cm})$
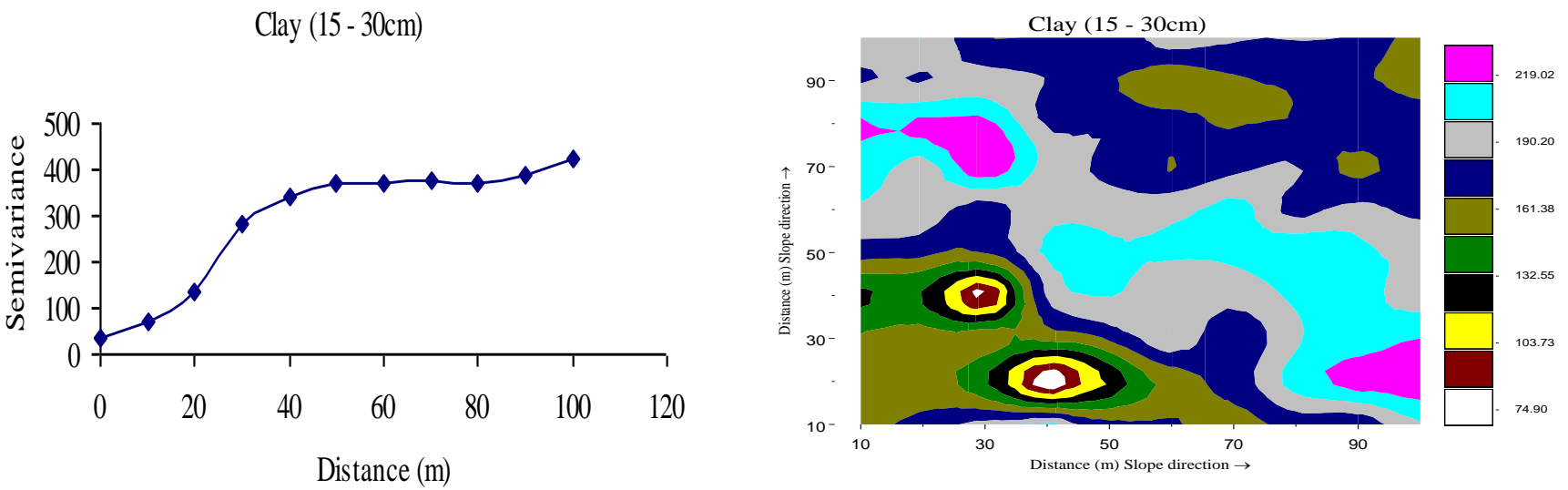

Fig. 4: Semivariograms (left) and kriged maps (right) of clay $\left(\mathrm{g} \mathrm{kg}^{-1}\right)$ for surface $(0-15 \mathrm{~cm})$ and subsurface $(15$ $-30 \mathrm{~cm})$ soils. 
spatial maps through ordinary kriging using the semivariogram parameters and linear model. The kriged maps helped in the estimation of the soil particle sizes at various unsampled locations in the study area in continuous contour maps (Fig. 2 - 7). It was observed that silt + clay was dominated by values that varied between $>172$ and $<195 \mathrm{gkg}^{-1}$ on the surface and between $>207$ and $<209 \mathrm{gkg}^{-1}$ at the subsurface with concentrations at the diagonals from the bottom left of the plot (Fig. 2). The map of distribution of coarse sand and fine sand (Fig. 6 and 7 ) on the surface and subsurface were very similar as a confirmation for the significant correlation established in both their contents and calculated semivariances. But maps of the surface were more similar than those of subsurface (Fig. 4 and 5) and the subsurface having more complex distribution of fine sand compared to the coarse sand. Generally, the trend of distribution of silt + clay was similar to those observed for coarse and fine sand. The predicted distribution of SCR (Fig. 3) in the one
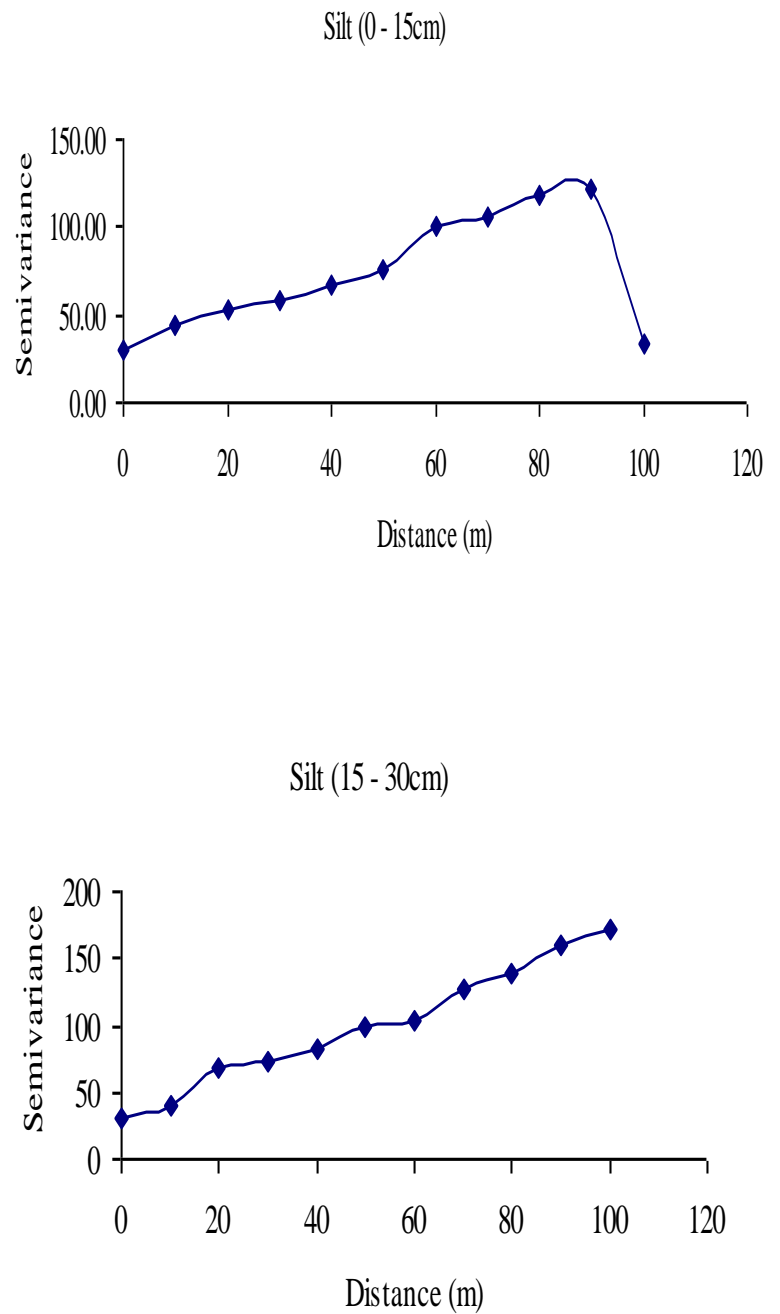

hectare plot has similar trend in both surface and subsurface soils, but with fewer clusters at the subsurface compared to the surface. The values of SCR that ranged between 0.1 and 0.2 occupied greater $85 \%$ of the one hectare plot.

The clay content (Fig. 4) of the subsurface had more complex distribution than the surface soil. In clay content, $>161$ but $<181 \mathrm{gkg}^{-1}$ (surface) and $>161,<191 \mathrm{gkg}^{-1}$ (subsurface) occupy $>75 \%$ of the plot studied. Silt (Fig. 5) content of the soil was found to be the lowest at the centre of the study area and increased outwards, generally $>20.3$ but $<27.2 \mathrm{~g}$ $\mathrm{kg}^{-1}$ occupied $>50 \%$ on the surface while between $>18.0$ and $<20.7 \mathrm{~g} \mathrm{~kg}^{-1}$ occupied $>75 \%$ (subsurface) of the hectare plot studied. It was observed that most of the maps displayed similarity in the sedimentation or depositional characteristics which now followed the depositional effect of the massive erosive forces or processes which may not be the direction of the initial deposition and sedimentation (may need to be investigated).
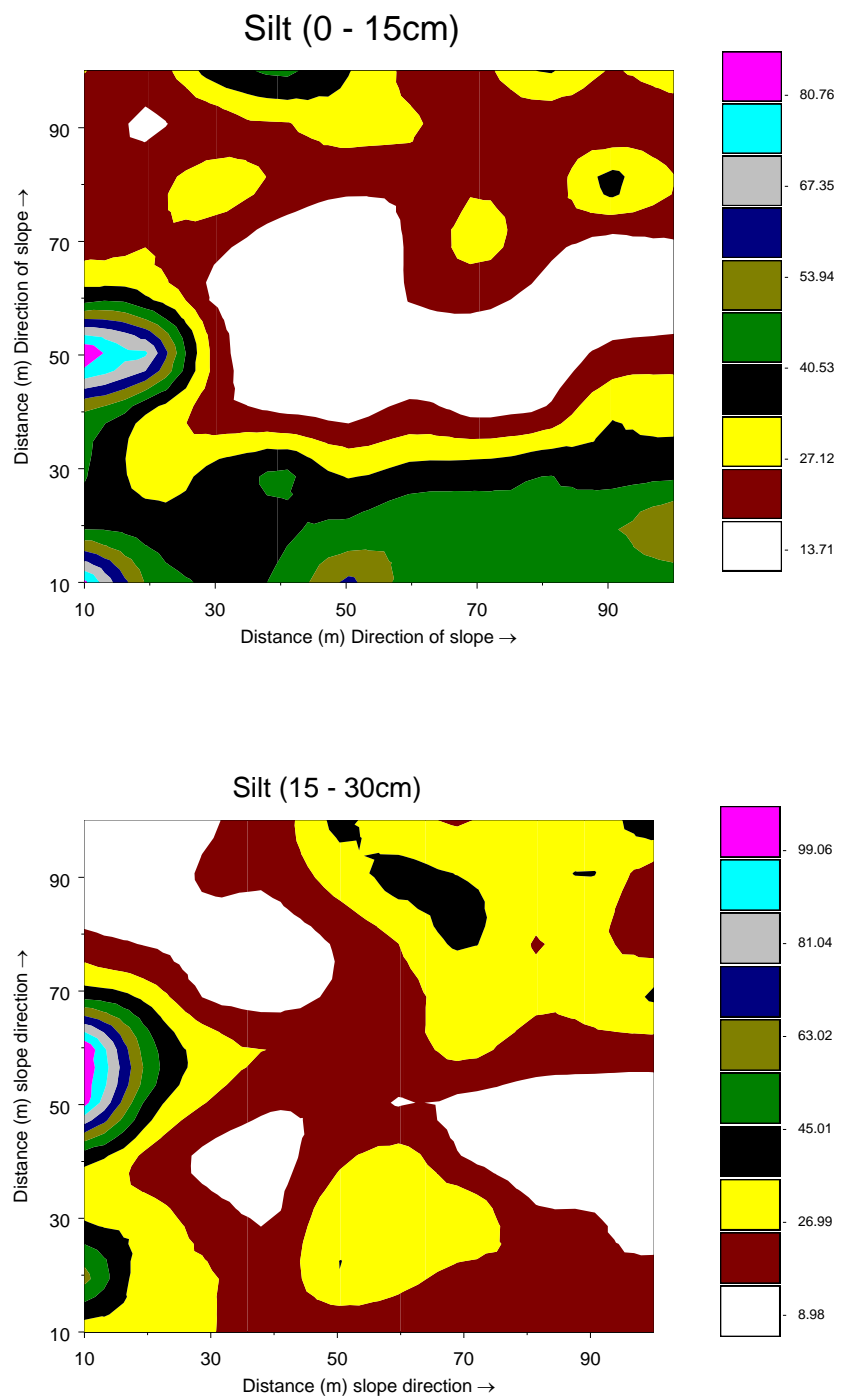

Fig. 5: Semivariograms (left) and kriged maps (right) of silt $\left(\mathrm{g} \mathrm{kg}^{-1}\right)$ for surface $(0-15 \mathrm{~cm})$ and subsurface $(15-30 \mathrm{~cm})$ soils. 
Fine sand $(0-15 \mathrm{~cm})$

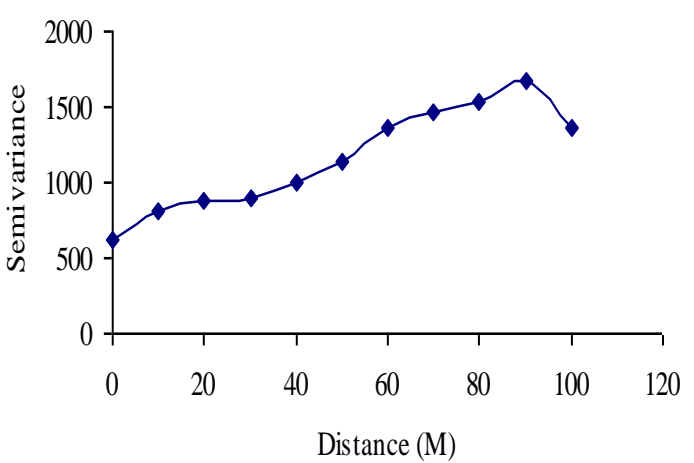

Fine sand $(15-30 \mathrm{~cm})$

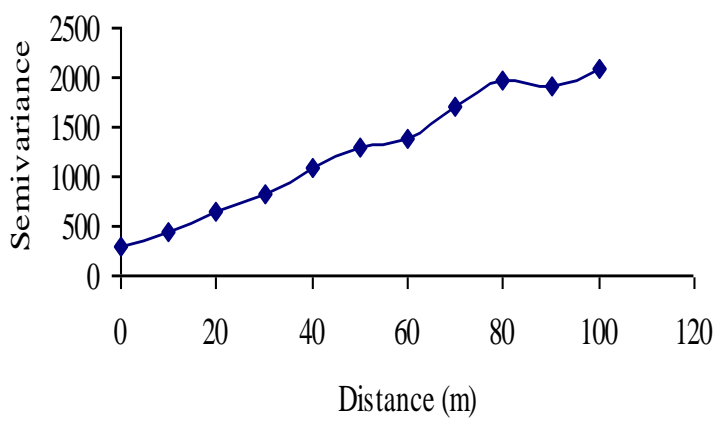

Fine sand $(0-15 \mathrm{~cm})$

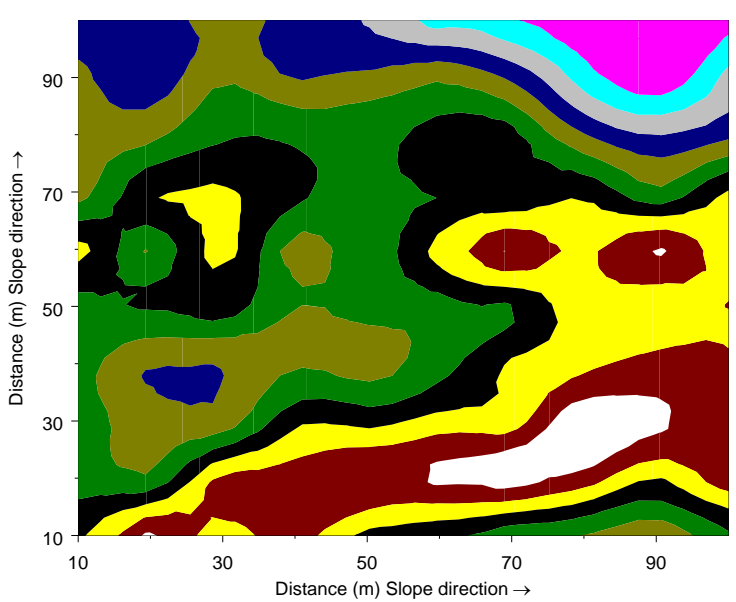

Fine sand $(15-30 \mathrm{~cm})$

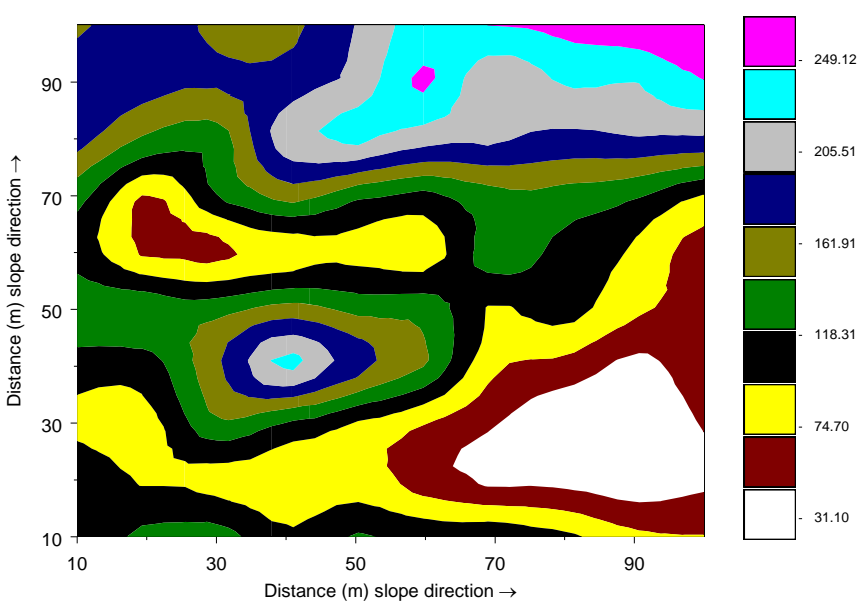

Fig. 6: Semivariograms (left) and kriged maps (right) of fine sand $\left(\mathrm{g} \mathrm{kg}^{-1}\right)$ for surface $(0-15 \mathrm{~cm})$ and subsurface $(15-30 \mathrm{~cm})$ soils. 
Coarse sand $(0-15 \mathrm{~cm})$

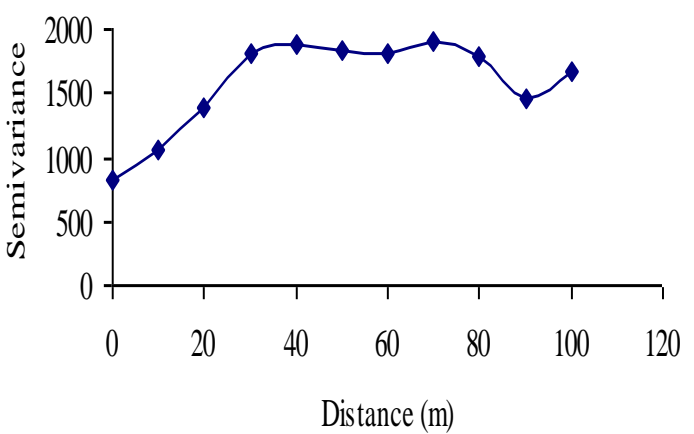

Coarse sand $(15-30 \mathrm{~cm})$

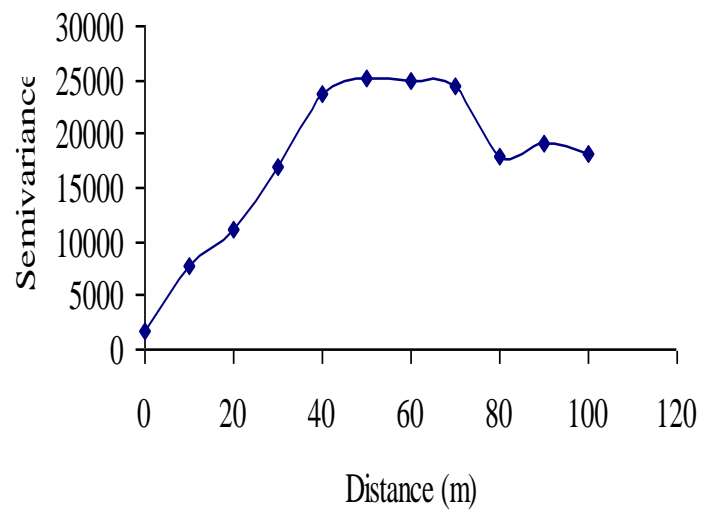

Coarse sand $(0-15 \mathrm{~cm})$
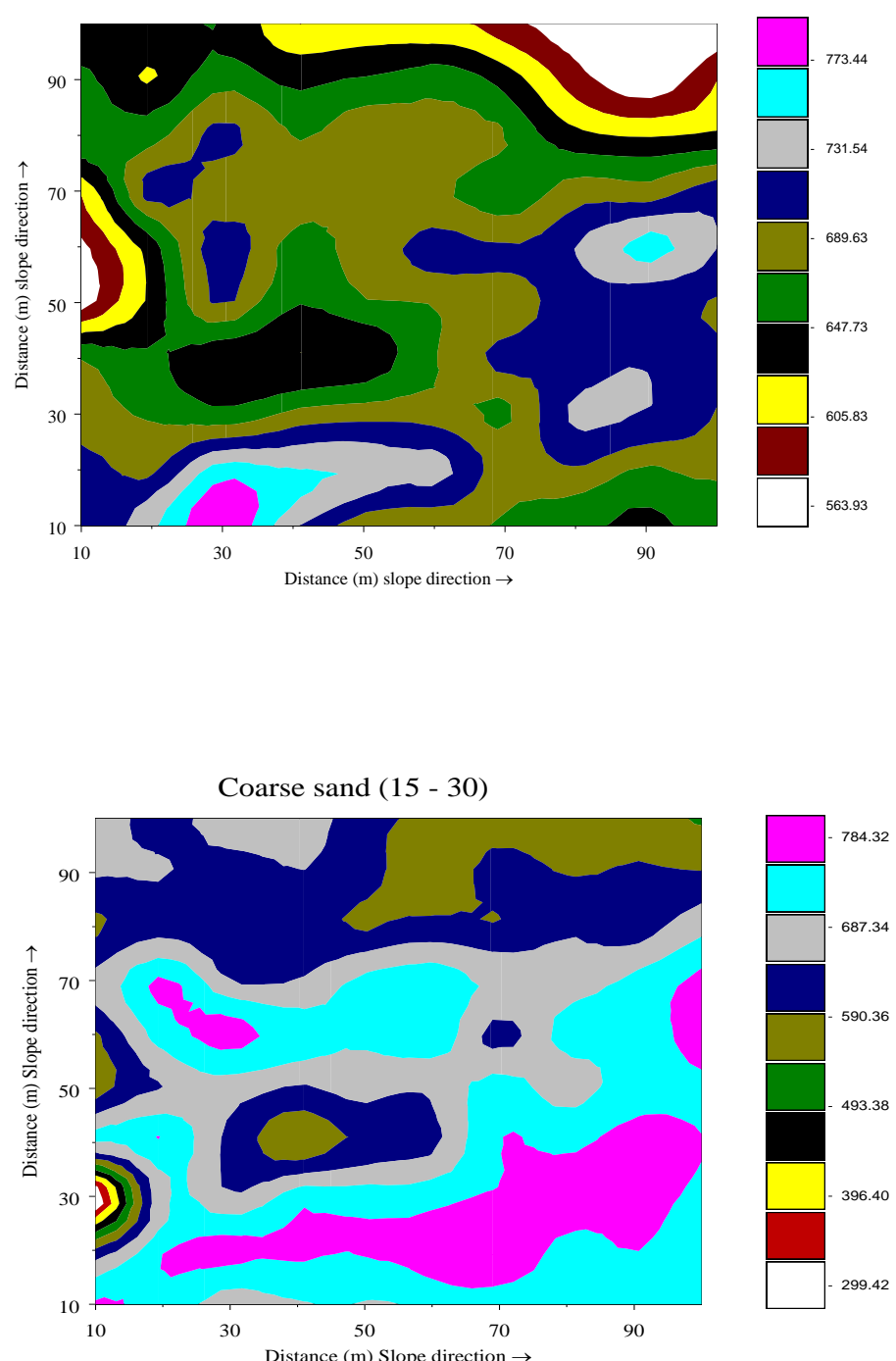

Fig. 7: Semivariograms (left) and kriged maps (right) of coarse sand $\left(\mathrm{g} \mathrm{kg}^{-1}\right)$ for surface $(0-15 \mathrm{~cm})$ and subsurface $(15-30 \mathrm{~cm})$ soils.

\section{CONCLUSIONS}

Particle size distribution influences other physical, invariably chemical and biological soil properties. Particle size distribution of coastal plain sands soils studied with the aid of classical and geostatistical analysis displayed variability, spatial dependence and spatial structure. It was observed that SCR, silt, fine and coarse sand (surface) were highly variable at both depths, while coarse sand (subsurface) was least variable. Correlation between the calculated semivariances at the two depths showed significance in 19 out of 36 relationships. This was in contrast to 7 out of 36 observed on the measured values of the variables. Strongly spatially dependent variables correlated with more of the other variables compared to the moderately spatially dependent variables. Generally, the spatial dependence of particle size distributions and their components ranged from strong to moderate. The moderately spatially dependent variables included fine sand, coarse sand on the surface, and SCR on the subsurface, while the remaining variables were strongly spatially dependent. It was observed that most of the maps displayed similarity in the sedimentation or depositional characteristics which now followed the depositional effect of the massive erosive forces or processes. Semivariance of fine sand could be most representative for the entire particle sizes and its kriged map may be used for management decision purposes and evaluation of pedogenesis under suitable circumstances. The kriged map in combination with correlation and spatial dependence may facilitate; (i) site specific farming and soil management through proper 
planning of inputs such as agrochemical, irrigation and land preparation, (ii) site selection in sanitary landfills management, (iii) knowledge of pedogenesis and subsequently sustainability and health in the coastal plain sands soils.

\section{REFERENCES}

Bailey, T. C., and Gatrell, A. C. 1998. Interactive spatial data analysis. Addison Wesley Longman, UK.

Botros, F. E., Harter, T, Onsoy, Y. S., Tuli, A. and Hopmans, J. W. 2009. Spatial variability of hydraulic properties and sediments characteristics in a deep alluvial unsaturated zone. Vadose Zone J. 8:276 - 289.

Cambardlla, C. A., Moorman, T. B., Novak, J. M., Parkin, T. B., Karlan, D. L., Turco, R. F. and Konopka, A. E. 1994. Field scale variability of soil prop-erties in Central Iowa soils. Soil Sci. Soc. Am. J. 58:15011511.

Clark, I. 1979. Practical geostatistics. Applied Sci. Publ., London.

Crave, A. and Gascuel-Odoux, C. 1997. The influence of topography on time and space distribution of soil surface water content. Hydrology: 11: $203-210$.

David, M. 1977. Geostatistics area reserve estimation. Elsevier Sci. Publ., Amsterdam.

Duffera, M., White, J. G. and Weisz, R. 2007. Spatial variability of southeastern U. S. Coastal Plain Soil physical properties: implication for site specific management. Geoderma 137:327 - 339 .

Gee, G. W., and Bauder, J. W. 1986. Particle size analysis. p. 404-407. In A. Klute (ed.) Methods of soil analysis. Part 1. 2nd ed. AgronMonogr. 9. ASA and SSSA, Madison, WI.

Goovaerts, P. 1997. Geostatistics for natural resources evaluation. Oxford Univ. Press, New York.

Haan, C. T. 1997. Statistical methods in hydrology. Iowa State Univ. Press, Ames.

Ibia, T. O., Uko-Haka, I. B., Edem, S. O., Ogban, P. I. and Obi, J. C. 2009. Evaluation of the acid soils for sanitary landfills in Akwa Ibom State, southeastern Nigeria. Book of Abstracts, 33rd Annual Conference of Soil Science Society of Nigeria, held at University of Ado Ekiti, Nigeria, 9 - 13th March, 2009. p34.
Iqbal, J., Thomasson, J. A., Jenkins, J. N., Owens, P. R. and Whisler, F. D. 2005. Spatial variability analysis of soil physical properties of alluvial Soils. Soil Sci. Soc. Am. J. 69:1338 - 1350 .

Journel, A.G., and Huijbregts, C. J. 1978. Mining geostatistics. Academic Press, London.

Mbagwu, J. S. C., Lal, R. and Scott, T. W. 1983. Physical properties of three soils in southwestern Nigeria. Soil Science 136(1): $48-55$.

McBratney, A. B., and Pringle, M. J. 1999. Estimating average and proportional variograms of soil properties and their potential use in precision agriculture. Precis. Agric. 1:219-236.

Obi, J. C. and Ogunkunle, A. O. 2009. Influence of termite infestation on the spatial variability of soil properties in the guinea savanna region of Nigeria. Geoderma, 148: 357 368.

Obi, J. C. and Nnadi, C. I. (2010). Spatial analysis of particle size distribution of basement complex soils in the southwestern Nigeria. Int'l Journal of Agri. \& Rural Dev. 13(2):204-213.

Obi, J. C., Awonuga, A. O. and Umeojiakor, A. O. 2010a. Spatial dependence of some physical properties of a typic plinthaqualf on the basement complex in southwestern Nigeria. Journal of Tropical Agriculture, food, Environment and Extension, 9(1):38 - 46.

Obi, J. C., Utuk, I. I. and Udo, B. U. 2010b. Spatial autocorrelation of particle sizes of soils formed on coastal plain sands in southeastern Nigeria. Proceedings of the 34th annual Conference of the Soil Science Society of Nigeria. $68-74$.

Ofomata, G. E. K. 1981. Actual and potential erosion in Nigeria and measures for control. In: E. J. Udo and R. A. Sobulo (eds) 'Acid sands' of southeastern Nigeria. Soil Sci. Soc. Nig. Spec. Public Monogr. No 1:151-165.

Ogban, P. I. and Ekerette, I. O. 2001. Physical and chemical properties of the coastal plain sands soils of southeastern Nigeria. Nig. J. Soil Res. 2: 6-14.

Ojanuga, A. G., Lekwa, G and Akamigbo, F. O. R. 1981. Survey, classification and genesis of acid sands. In: E. J. Udo and R. A. Sobulo (eds) 'Acid sands' of southeastern Nigeria. Soil Sci. Soc. Nig. Spec. Public Monogr. No 
$1: 1-7$

Olaleye, A. O., Ogunkunle, A. O. and Sahrawat, K. L. 2000. Forms and pedogenic distribution of extractable iron in selected wetland soils in Nigeria. Commun. Soil Sci. Plant Anal. 31(7\&8): 923-941.

Parkin, T. B. and Robinson, J. A. 1992. Anslysis of lognormal data. Adv. Soil Sci. 20:193 325 .

Peters, S. W., Usoro, E. J., Udoh, E. J., Obot, U. W. and Okpon, S. N. 1989. Akwa Ibom State: Physical background, Soils and land use and ecological problems. Government Print Office, Uyo, 603p.

Reynolds, S. O. 1970. The gravimetric methods of soil moisture determination. I. A study of equipment and methodological problems. Hydrology, 11: 258 - 273.

Santra, P., Chopra, U. K. and Chakraborty, D. 2008. Spatial variability of soil properties and its application in predicting surface map of hydraulic parameters in an agricultural farm. Current Science, 95(7): 937 - 945.

SAS Institute. 1989. SAS/STST User's Guide, Version 6, 4th Ed, Vol. 1 and 2. SAS Institute, Carry, NC 327.

Shapiro, S. S., and Wilk, M. B. 1965. An analysis of variance test for normality. Biometrika 52:691-710.

Shukla, M. K. Slater, B, K., Lal, R. and Cepuder, P.
2004. Spatial variability of soil properties and potential management classification of a chernozemic field in lower Austria. Soil Science 169: 852-860.

Souza, Z. M., Júnior, J. M. and Pereira, G. T. 2009. Spatial variability of the physical and mineralogical properties of the soil from the areas with variation in landscape shapes. Braz. Arch. Biol. Technol. 52 (2): 305-316.

S-Plus. 1997. S-Plus SpatialStats user's manual for Windows and Unix. Data Analysis Product Division, MathSoft, Seattle, WA.

Strock, J. S., Cassel, D. K. and Gumpertz, M. L. 2001. Spatial variability of water and bromide transport through variably saturated soil blocks. Soil Sci. Soc. Am. J. 65: $1607-$ 1617.

Trangmar, B. B., Yost, R. S. and Uehara, G. 1985. Application of geostatistics to spatial studies of soil properties. Advances in Agronomy. Vol. 38: 45-94.

Vauclin, M., Viera, S. R., Vachaud, G. and Nielsen, D. R. 1983. The use of co-kriging with limited field soil observations. Soil Sci. Soc. Am. J. 47:175-184.

Warrick, A. W. and Gardner, W. R. 1983. Crop yield as affected by spatial variation of soils and irrigation. Water Resource, 19: 181 - 186. 